\title{
NDC80 wt Allele
}

National Cancer Institute

\section{Source}

National Cancer Institute. NDC80 wt Allele. NCI Thesaurus. Code C152015.

Human NDC80 wild-type allele is located in the vicinity of $18 \mathrm{p} 11.32$ and is approximately $45 \mathrm{~kb}$ in length. This allele, which encodes kinetochore protein NDC80 homolog protein, is involved in chromosome segregation and mitotic spindle checkpoint activity. 